\title{
Analysis of the Risks arising from Fire Installations in Workplaces using the Ranking Method
}

\author{
Fatih Yilmaz \\ Department of Labour Economics and Industrial Relations \\ Bandirma Onyedi Eylul University \\ Balikesir, Turkey \\ fatihyilmaz@bandirma.edu.tr
}

Beytullah $\mathrm{Oz}$

Department of Chemical Engineering

Corum Hitit University

Corum, Turkey

beytullahoz@hitit.edu.tr

\author{
Selcuk Alp \\ Department of Industrial Engineering \\ Yildiz Technical University \\ Istanbul, Turkey \\ alp@yildiz.edu.tr \\ Ahmetcan Alkoc \\ Department of Industrial Engineering \\ Yildiz Technical University \\ Istanbul, Turkey \\ acanalkoc@gmail.com
}

\begin{abstract}
The aim of this study is to analyze the risks arising from fire installations in workplaces. It also aims to propose a risk analysis method in the form of a "Fire Safety Risk Ranking System" for enterprises with a closed work area of more than $1000 \mathrm{~m}^{2}$ in accordance with regulations in Turkey. The relative weights of fire safety factors were determined by Fuzzy AHP. The ranking points of the enterprises were calculated by using the weights obtained with FAHP. From the 45 enterprises where the risk assessment was applied, only 3 enterprises scored 100 full points according to the fire risk ranking method, and 30 enterprises had a score below 80 points. Out of these, 6 scored below 60 points, which is considered a low score. The distribution of enterprises within sectors was not equal. According to the results, only $6.6 \%$ of the enterprises are in compliance with legislation and standards, about $67 \%$ are inadequate in terms of fire safety and continue to operate under serious fire risks.
\end{abstract}

Keywords-arising risks; ranking method; fuzzy AHP; fire installatilons

\section{INTRODUCTION}

The number of factory fires in Turkey in 2017 showed $7.8 \%$ and $25.9 \%$ increase compared to 2016 and 2014. According to the Instanbul Metropolitan Municipality [1] Statistics in 2017, a total of 166 Fire Department interventions in factories were reported [1]. Along with the developing technology and legal obligations, the importance of fire risk assessment and establishment and supervision of fire safety systems has been increased in order to create a safer working environment for the employees and the people living near the factory. In accordance with the Occupational Health and Safety Act in Turkey, employers are obliged to assess risks for the identification and elimination of hazards that may or may not exist in workplaces. Keeping the risk assessment as up-to-date as possible it is also important in terms of ensuring the continuous improvement at the workplace [2]. Periodic inspections of fire installations are mandatory at least once a year in Turkey. There are similar applications in many countries. The Regulation on the Protection of Buildings from Fire also aims at minimizing the fires that can occur during the stages of design, construction, operation, maintenance and use of all types of structures and facilities. Its aim is to ensure that the loss of life or property is minimized and eliminated, and regulations published to determine the basis for the organization, training and inspection procedures and principles of the measures to be taken before and during the fire. Sensitive equipment used in enterprises, high-rise and multi-purpose buildings and valuables kept in warehouses bring about various risks. Safety measures have changed as new risks arise. One of the most important of these risks is fire due to its destructive consequences, so new safety measures are being developed to eliminate fire risks. The number of new devices and systems that detect, warn, and provide suitable solutions is increasing. By considering the potential damage that fire can cause in enterprises, fire protection, extinguishing and security systems are getting more important every day [3]. In order to determine the most appropriate safety measures against fire in the premises or in public places such as shopping malls, hospitals, and schools, the risk of fire must be determined realistically and appropriate methods should be developed. Fire risks are also addressed by various risk assessment techniques [4]. Fire risk analysis aims to determine the criteria that define risk, its importance level, and ways to set prevention and protection measures in order to reduce these risks [5].

When each designed structure is examined from a risk analysis point of view, it is assumed that the possibility of fire cannot be eliminated. For this reason, it is not possible to ensure perfect fire safety. However, it is important to examine fire protection and fire safety issues in a holistic and systematic way to reduce risks. First, it is necessary to identify the criteria and the importance ratings of these criteria in line with a plan, then form and formulate a strategy that will satisfy these criteria and lead to the identified targets [6]. Fire is a disaster 
that may cause death, injury, and major financial loss. Fire risks vary widely and some of these risks are due to fire installations. Fire risk analyses based on standards in the form of a detailed but traditional checklist may produce unrealistic results for older fire installations. For this reason, new and more holistic approaches need to be implemented.

This article proposes a risk analysis method considering the Fire Safety Risk Ranking System for enterprises in Turkey. For this purpose, a survey was carried out in 45 enterprises with a closed area of more than $1000 \mathrm{~m}^{2}$, in accordance with the Regulation on the Protection of Buildings from Fire, which entered into force in 2007. The fire safety criteria used in calculating the risk score are based on national and international legislations and standards. These criteria are building properties, fire safety systems, and management systems. First, the weights for these criteria were determined by the Fuzzy Analytical Hierarchy Process (FAHP) method. For this intent, a questionnaire was applied to fire experts. Calculated weights were recalculated by ranking method, and fire risk score and ranking charts were prepared for the enterprises.

\section{LITERATURE REVIEW}

Authors in [7] proposed the nonlinear FAHP in the coal mine safety assessment, compared it to AHP, and found it to be more appropriate, precise, and complete in the evaluation process. Authors in [8] examined the social benefits of occupational health and safety management systems of mines in China and Sweden based on FAHP with a comparative study. Authors in [9] determined and evaluated the risk of modular structure using FAHP and simulations. In [10], an FAHP approach was proposed to determine the level of Faulty Behavior Risk in work systems. Their proposed method was applied to a manufacturing company. Authors in [11] established an FAHP assessment model for gas station safety status. In [12], a risk assessment methodology for conducting systematic risk assessment using fuzzy reasoning approach and FAHP was presented. The purpose of the authors in [13] was to compare how Canadian experts and public rank different food hazards, with a view to better understand their underlying rationales for making decisions on food safety. Authors in [14] studied the accident risk ranking of the major facility hazards. Consequently, a risk ranking model and methods for determining scenario probability and fatality number were developed. In [15], a new reliability interval method for manipulating the weightings of attributes and a synthetic model on the basis of grey system theory was presented. In [16], a fire safety ranking system, excluding the fire safety management at the moment, was proposed for assessing the fire safety provisions for existing karaoke establishments in Hong Kong. Authors in [17] evaluated the fire risks of public buildings by using simultaneously the AHP and Fault Tree Analysis (FTA) methods. FTA reflects how important Key Events are for the Most Important Event. AHP also reflects the importance of the alternative level attribute to the general goal. Based on the consistency of these two methods, an improved AHP was introduced. Using this improved method, fire safety of public buildings (Olympic venues in China) was analyzed. Authors in [18] developed an approach to integrate ship fire safety assessment and decision making using the AHP method. They suggested that this approach could be used to reduce the likelihood of a fire during the operating phase of a cruise ship and the severity of its possible consequences. AHP method has been used to sort fire incidents and an integrated system has been proposed to minimize fires using the obtained results. In [19], a new approach was presented for the rapid assessment and relative ordering of the hazards of chemicals, installations and facilities. This approach is based on the use of a multicriteria decision-making technique based on fuzzy logic for hazard assessment of substances and facilities. Based on the proposed method, the Substance Fire Hazard Index (SFHI) and Consequences Index (CI) have been developed to evaluate the results of the potential of an accident at the facility.

In this study, in contrast with the studies given above, Ranking Method, which is frequently used in occupational safety, and FAHP, which is a multi-criteria decision making method in fuzzy environment, were used simultaneously. In this way, more consistent results were obtained. Moreover, by using the obtained results (weighted fire safety criteria), the applicability of the method was shown.

\section{METHODS}

The safety of work systems is affected by many factors. Therefore, measuring work system safety requires a holistic approach [7]. In this study, the work safety issue is studied through the FAHP approach, which allows multi-criteria and simultaneous evaluation, and the Ranking Method.

\section{A. Multi-Criteria Decision-Making}

The decision-making problem can be defined in the most general sense as the choice of the most appropriate option according to at least one objective or criterion from a set of choices. Decision-making is a very difficult task when many parameters determine the goal to be reached in a problem and where each of the alternatives to be evaluated for selection has its own advantages. The aim of using MCDM methods is to keep the decision-making mechanism under control and to get the decision result as easy and quick as possible [20]. Various scientific methods have been put forward in order to find solutions to decision-making problems with more than one criteria. These solution methods are called MCDM methods [21]. MCDM is a selection process that a decision maker applies using a minimum of two criteria in a set of countable finite or uncountable number of choices [22].

\section{B. Fuzzy Analytical Hierarchy Process}

The AHP is one multi-criteria decision-making method developed by Thomas L. Saaty in the 1970s. The AHP, which is based on human-natured binary comparisons, assesses how important, preferential, or dominant these binary comparisons, options and criteria are to each other [23]. This method of determining the best option is often used to solve complex decision problems due to both quantitative and qualitative factors considered and its ease of use [24]. Despite the fact that it finds application in many decision problems, it has not been accepted without criticism. For starters, the uncertainties regarding the decisions, criteria and alternatives in the evaluations made with AHP are not taken into consideration 
and this affects the decision to be made to a great extent [25]. If a worse alternative than the existing alternatives is added in a decision problem solved by the AHP method, the order of the alternatives is likely to change. This shows that decisionmaking problems solved by the AHP method may not always give accurate results. FAHP method produces more precise results compared to the AHP method [26, 27]. While decision makers in AHP use exact values when making their assessments, evaluations that are more accurate can be made using fuzzy numbers or linguistic variables in FAHP. Various FAHP methods have been suggested [20, 27]. As an example of these methods, Van Laarhoven and Pedryey's direct expansion of Saaty's AHP method with triangular fuzzy numbers method, Buckley's method of developing the Saaty's AHP method with aij fuzzy comparison rates, the extended FAHP method proposed by Cheng, the FAHP method based on entropy weight, the limited FAHP method and enumeration methods of fuzzy numbers revealed by Enea and Piazza can be given [21].

In the fuzzy set theory, the ratio provided by the decision makers is a fuzzy number, which is defined as a membership function. The membership function defines the value of the elements in the decision interval of the priority set. It would be more appropriate for the experts to give verbal assessments instead of a definite number of opinions on one subject. These verbal evaluations are the Triangular Fuzzy Numbers (TFN) [27], shown as $(1|m, m| u)$ or $(1, m, u)$. For a fuzzy event, the parameters $l, m, u$ show the smallest possible value, the most expected value and the largest possible value respectively [28].

The extended FAHP method proposed in [29] is used in this study. The steps for this method are outlined below.

Step 1: The fuzzy synthetic dimension value according to the object $i$ is calculated as in (1):

$$
S_{i}=\sum_{j=1}^{m} M_{g i}^{j} \otimes\left[\sum_{i=1}^{n} \sum_{j=1}^{m} M_{g i}^{j}\right]^{-1}
$$

The sum of the $m$ dimension analysis matrix $\sum_{j=1}^{m} M_{g i}^{j}$ in (1) is calculated by (2):

$$
\sum_{\mathrm{j}=1}^{\mathrm{m}} \mathrm{M}_{\mathrm{gi}}^{\mathrm{j}}=\left(\sum_{\mathrm{j}=1}^{\mathrm{m}} \mathrm{l}_{\mathrm{j}} \sum_{\mathrm{j}=1}^{\mathrm{m}} \mathrm{m}_{\mathrm{j}} \sum_{\mathrm{j}=1}^{\mathrm{m}} \mathrm{u}_{\mathrm{j}}\right)
$$

Again, fuzzy addition is performed on the $M_{g i}^{j}$ values to compute the $\left[\sum_{i=1}^{n} \sum_{j=1}^{m} M_{g i}^{j}\right]^{-1}$ expression in (1). At the end of this step, the inverse vector is calculated by:

$$
\left[\sum_{i=1}^{n} \sum_{j=1}^{m} M_{g i}^{j}\right]^{-1}=\left(\frac{1}{\sum_{i=1}^{n} u_{j}}, \frac{1}{\sum_{i=1}^{m n} m_{j}}, \frac{1}{\sum_{i=1}^{n} l_{j}}\right)
$$

Step 2: The $\left.M_{2}\left(l_{2}, m_{2}, u_{2}\right) \geq M_{1}\left(l_{1}, m_{1}, u_{1}\right)\right)$ probability value, with $M_{1}, M_{2}$, being TFNs, is calculated in (4):

$$
V\left(M_{2} \geq M_{1}\right)=\sup _{y \geq x}\left[\min \left(\mu_{M_{1}}(x), \mu_{M_{2}}(y)\right)\right]
$$

The expression $V\left(M_{2} \geq M_{1}\right)$ in (4) is calculated as:

$$
V\left(M_{2} \geq M_{1}\right)=\operatorname{hgt}\left(M_{1} \cap M_{2}\right)=\mu M_{2}(d)
$$

$$
V\left(M_{2} \geq M_{1}\right)=\left\{\begin{array}{cl}
1 & ; m_{2} \geq m_{1} \\
0 & ; l_{1} \geq u_{2} \\
\left.\frac{\left(l_{1}-u_{2}\right)}{\left(m_{2}-u_{2}\right)-\left(m_{1}-l_{1}\right)}\right) & \text { otherwise }
\end{array}\right.
$$

Step 3: The likelihood of the probability level of a convex fuzzy number is greater than $k$ convex numbers $M_{i}$ $(\mathrm{i}=1, .2, \ldots, \mathrm{k})$ is calculated as:

$$
V\left(M \geq M_{1}, M_{2}, \ldots, M_{k}\right)=\min V\left(M \geq M_{i}\right)
$$

It is assumed that $\mathrm{d}^{\prime}\left(A_{1}\right)=\min \left(V\left(S_{i} \geq S_{k}\right)\right)$ for $i=1,2, \ldots, k$ and $k \neq \mathrm{i}$ and so the weight vector $\left(W^{\prime}\right)$ is calculated by:

$$
W^{\prime}=\left(d^{\prime}\left(A_{1}\right), d^{\prime}\left(A_{2}\right), \ldots, d^{\prime}\left(A_{n}\right)\right)^{T}
$$

The form $A_{i}$ in the formula consists of $n$ elements $(i=$ $1,2, \ldots, n)$.

Step 4: The weight vector given in (7) is the normalized weight vector $W=\left(d\left(A_{1}\right), d\left(A_{2}\right), \ldots, d\left(A_{n}\right)\right)^{T}$ after the normalization process. The calculated weight vector $W$ is no longer a fuzzy number [16].

\section{Ranking Method}

This method is known as the fire safety ranking system, the fire risk ranking system or the fire safety assessment system in scientific studies [20-33]. It is a process where the ranking of fire safety criteria is made by using multi criteria decisionmaking [23, 33-36]. The purpose of a fire safety ranking system is to assess the performance of various fire safety criteria of existing buildings and to measure the level of fire risk. The fire risk levels obtained are the basis for prioritizing the actions to be taken to improve fire safety performance [31]. In many countries, fire safety risk ranking methods have been developed and implemented to help assess the fire safety level of buildings. For example, a Fire Safety Assessment System was developed based on fire risk ranking in the United States [37]. This system offers a multi-featured approach to determining equivalencies to the NFPA 101 Life Safety Standard for specific workplaces [38]. Authors in [39] have proposed a fire safety ranking system for entertainment venues in Hong Kong. Another application of the ranking method, similar to our study, was used to determine the fire safety performance of student accommodation enterprises in Saudi Arabia [30].

Fire risk ranking systems offer many advantages, such as ease of use, cost effectiveness, and a quick and simple estimation of the relative risk of fire. To the best of our knowledge, there is no other study using the ranking method for the analysis of risks from fire installations. Ranking method has been used in other similar areas, such as maintenance management, improvement of building security systems, and prioritization of materials [30, 40]. However, there are disadvantages in using fire safety ranking systems. To begin with, it is not a uniform system. For this reason, it is stated that different methods should be developed for different usage type structures [41]. The basic assumption of the ranking method is the existence of the relative importance levels of fire risk factor criteria against each other. Different enterprises have different fire risk criteria. However, these criteria can increase or 
decrease the total fire risk level. Moreover, uniform risk analyzes made with the $0-1$ or present/not present checklist do not contain sufficient numerical data, which makes evaluation of fire risks difficult and reduces accuracy.

The purpose of this method is to calculate the importance of each risk criterion with the FAHP, which is an MCDM method according to the opinions of fire experts. The calculated risk scores are then reflected to the application of the risk analysis in the enterprises and the total fire risk score is calculated for the enterprises. With this method, fire risks are calculated quantitatively and the sensitivity level of risk assessment increases. In this way, quantitative data are produced in the planning of preventive activities, with the determination of the measures and priorities to be taken care of in the business, which can support the occupational health and safety experts. This study, prepared by the fire risk ranking method, was carried out in three stages. In the first stage, each risk factor for the fire installations of enterprises was determined in accordance with the current legislations and standards. Subsequently, the criteria and sub-criteria specified in Tables II and III were determined by a questionnaire applied to fire experts. The results obtained were calculated by the FAHP method and the weighted risk scores of each fire safety criterion and its sub-criteria were determined. In the second phase, the weighted risk scores calculated with FAHP were multiplied by the risk scores obtained from the risk analysis application conducted by the control list method in the enterprises within the scope of application, and the total risk score for each enterprise was determined. In the last stage, figures obtained from the total risk scores and the fire risk ranking score chart of the enterprises were drawn.

\section{DATA COLLECTION AND RESUlTS}

\section{A. Data Collection}

In order to develop a fire risk ranking system within the scope of the research, a survey was prepared in accordance with the FAHP method to calculate the weight of fire safety criteria and sub-criteria determined according to the literature review and current standards. The study has simplified the fire safety criteria and qualifications in paired comparison tables, as shown in Table I.

TABLE I. DOUBLE-SIDED COMPARISON SCALE

\begin{tabular}{|c|c|c|c|c|c|c|c|c|c|}
\hline & $\mathbf{9}$ & $\mathbf{7}$ & $\mathbf{5}$ & $\mathbf{3}$ & $\mathbf{1}$ & $\mathbf{3}$ & $\mathbf{5}$ & $\mathbf{7}$ & $\mathbf{9}$ \\
\hline $\mathbf{X}$ & $\begin{array}{c}\text { Absolutely } \\
\text { important }\end{array}$ & $\begin{array}{c}\text { Very } \\
\text { important }\end{array}$ & Important & $\begin{array}{c}\text { Somewhat } \\
\text { important }\end{array}$ & $\begin{array}{c}\text { Equally } \\
\text { important }\end{array}$ & $\begin{array}{c}\text { Somewhat } \\
\text { important }\end{array}$ & $\begin{array}{c}\text { Important } \\
\text { Very } \\
\text { important }\end{array}$ & $\begin{array}{c}\text { Absolutely } \\
\text { important }\end{array}$ & Y \\
\hline
\end{tabular}

TABLE II. TOTAL RELATIVE IMPORTANCE OF FIRE SAFETY FACTORS

\begin{tabular}{|c|c|c|}
\hline Fire safety factor & Relative weight calculation & Fire safety criteria \\
\hline Building properties & 0.4217 & Structural status of the building \\
\hline \multirow{2}{*}{ Fire safety systems } & & Pump system \\
& 0.4762 & Fire cabinets and cylinders \\
\cline { 2 - 3 } & & Fire extinguishing systems \\
\hline Management systems & 0.1021 & Firefighting and fire precautions \\
\hline
\end{tabular}

Responses were collected through personal interviews with fire experts with 20 years or more of experience. The questionnaire was applied to five specialists. The participants were asked to set the fire risk criteria given on each line in the questionnaire according to the other risk criteria specified at the end of the line. For example, if two criteria are equally important, it is desirable to mark the "1 Equally important" box, if the criterion in the right column is very important, the "7 Very important" box on the right side and the "3 Slightly important" on the left. The FAHP method was used to calculate the criterial weights by a matrix based on the scores in the questionnaire. The calculated values are given in Tables II and III. The questionnaire was presented as comparative titles for the detailed calculation of the risk factors and the weighted scores of the criteria and sub-criteria were identified as "building properties", "fire safety systems" and "management systems". Table II summarizes the six fire safety criteria. For calculating the total relative weight of each fire safety factor, measures were compared by experts and the results were given. Then, weights of the fire safety criteria were summed up to form the total weight of the fire safety factors. In Table III, the experts compared the sub-criteria representing "building structural condition criteria" and firefighting and fire precautions sub-criteria representing "management systems criteria". The sub-criteria of the pump system, fire cabinets and tubes, emergency exits, fire extinguishing system, fire detection and smoke control systems, which represent the "fire safety systems criteria", were compared and evaluated by experts in separate tiles. In addition, risk ranking is presented as a percentage of the relative fire safety criteria weighted in Table III.

\section{B. Application of Fire Risk Analysis with the Ranking Method}

The application was made in 45 enterprises in Istanbul with total indoor usage area more than $1000 \mathrm{~m}^{2}$, in which it is obligatory to have a water extinguishing system according to the relevant legislation. The fire safety criteria and the subcriteria set out in Table III are in accordance with the standards set by the Health and Safety Conditions Regulation for the Use of Work Equipment which entered into force in 2013 and the Regulation on Fire Protection of Buildings which entered in force in 2007. The inspections at the enterprises were carried out in cooperation with the occupational safety experts in order to ensure that measures were made in accordance with the criteria presented in Table III, as accurately as possible. The evaluated as appropriate installations were given a value of 1 whereas inappropriate were given a value of 0 . 
TABLE III. RELATIVE IMPORTANCE VALUES CALCULATED FROM FIRE SAFETY SUB-CRITERIA

\begin{tabular}{|c|c|c|c|c|}
\hline \multirow{2}{*}{ Fire safety factors } & \multirow{2}{*}{ No } & \multirow{2}{*}{ Fire safety criteria } & \multicolumn{2}{|c|}{ Weights } \\
\hline & & & Local & Global \\
\hline \multirow{5}{*}{ Pump system } & A1 & Pump station & 0.00630750 & \multirow{5}{*}{0.0319} \\
\hline & $\mathrm{A} 2$ & Spare diesel engine propulsion pump or electric pump (with generator support) & 0.00516780 & \\
\hline & A3 & Fire pumps sequential regular work & 0.00480240 & \\
\hline & A4 & All components of the pumps work or not & 0.00936410 & \\
\hline & A5 & Pump station & 0.00630750 & \\
\hline \multirow{5}{*}{ Fire cabinets and cylinders } & $\mathrm{B} 1$ & Fire tubes & 0.00609000 & \multirow{5}{*}{0.0290} \\
\hline & B2 & Fire cabinet & 0.00609000 & \\
\hline & B3 & Fire hose & 0.00609000 & \\
\hline & B4 & Fire valve & 0.00609000 & \\
\hline & B5 & Fire cabinet and tube warning signs, maintenance records and instructions & 0.00464000 & \\
\hline \multirow{5}{*}{$\begin{array}{l}\text { Emergency exits, fire detection, } \\
\text { and smoke control systems }\end{array}$} & $\mathrm{C} 1$ & Escape staircases on the buildings, fire resistant doors & 0.04720480 & \multirow{5}{*}{0.2896} \\
\hline & $\mathrm{C} 2$ & Suitable dimensions of escape routes & 0.05838336 & \\
\hline & $\mathrm{C} 3$ & Smoke flame detectors and audible warning systems & 0.06840352 & \\
\hline & $\mathrm{C} 4$ & Alarm systems and energy sources & 0.06840352 & \\
\hline & $\mathrm{C} 5$ & Exit signs and emergency lighting & 0.04720480 & \\
\hline \multirow{5}{*}{ Firefighting and fire precautions } & D1 & Emergency action plan & 0.02390161 & \multirow{5}{*}{0.1021} \\
\hline & D2 & Fire drill training & 0.02288061 & \\
\hline & D3 & Fire crew instructions & 0.01412043 & \\
\hline & D4 & Fire panel & 0.01412043 & \\
\hline & D5 & Periodic inspection report of fire system & 0.02707692 & \\
\hline \multirow{5}{*}{ Structural status of the building } & E1 & Building fire installation project & 0.08324358 & \multirow{5}{*}{0.4217} \\
\hline & E2 & Differences in installation metrics and application in the building installation project & 0.11963629 & \\
\hline & E3 & Materials used in the structural state of the building & 0.09420778 & \\
\hline & E4 & $300 \mathrm{~mA}$ fire alarm on the main panel in the electrical installation & 0.05047749 & \\
\hline & E5 & Electrical interior installation and ground measurements & 0.07413486 & \\
\hline \multirow{5}{*}{ Fire extinguishing systems } & F1 & Mains, fire water, hydrant lines, and tank connections & 0.02340520 & \multirow{5}{*}{0.1286} \\
\hline & $\mathrm{F} 2$ & Flow rates and pressures of fire pumps & 0.02694170 & \\
\hline & F3 & Raw water storage and sufficiency & 0.02655590 & \\
\hline & F4 & Sprinkler system project suitability & 0.02494840 & \\
\hline & F5 & Fire resistance test & 0.02674880 & \\
\hline
\end{tabular}

Step-by-step analysis follows:

$$
\begin{aligned}
& F S_{i}=\sum F S S_{i}=s_{i} * a_{i} \\
& \text { FSCFS }_{i}=S_{i} * A_{i} \\
& F S=F S C F S_{i}
\end{aligned}
$$

where FS is the Final Score, FSCFS is the Fire Safety Criteria Final Score, $S_{i}$ is the Fire Safety Criterion Score, $A_{i}$ the Fire Safety Criteria Weight, FSSCFS the Fire Safety Sub-Criteria Final Score, $s_{i}$ the Fire Safety Subscale Score, and $a_{i}$ the Fire Safety Sub-Criteria.

- Each fire safety criterion in Table III has been converted into scores based on the data of Table IV.

- The weighted risk score for each criterion was calculated by multiplying these scores by the weighted scores calculated by the FAHP method presented in Table III.

- To obtain the final score for each risk factor (building characteristics, fire safety systems and management systems), the outcome scores of all sub-criteria derived in stage 2 under each criterion were summed and multiplied by the weighted scores calculated for the criteria in Table II.

- The sum of the final scores of the criteria is the final total score of the enterprise.
- Fire safety rankings of the enterprises were made as a result of comparison of the general scores.

\section{Results}

The total working area of all the installations examined in the study is $>1000 \mathrm{~m}^{2}$ and all of them have a sprinkler system. Table IV provides general information of the enterprises.

TABLE IV. GENERAL INFORMATION

\begin{tabular}{|c|c|c|}
\hline Information & Feature & Frequency \\
\hline \multirow{3}{*}{ Hazard class } & Less dangerous & 11 \\
\cline { 2 - 3 } & Dangerous & 28 \\
\cline { 2 - 3 } & Very dangerous & 6 \\
\hline \multirow{4}{*}{ Sector } & Accommodation operations & 3 \\
\cline { 2 - 3 } & Administrative building & 2 \\
\cline { 2 - 3 } & Hachine production & 5 \\
\cline { 2 - 3 } & Mextile & 25 \\
\cline { 2 - 3 } & Warehouse & 5 \\
\cline { 2 - 3 } & & 5 \\
\cline { 2 - 3 }
\end{tabular}

The risk scores of the installations were obtained by multiplying the control scores with sub-criteria weights. The highest and lowest 8 total risk scores according to the fire safety risk factors are given in Table V. Table VI shows the mean and weighted mean values of fire safety risk factors for the enterprises. In order to determine the normalized weighted mean values, the mean values calculated for the enterprises and the weighted values which were previously found with the fuzzy analytical hierarchy process were considered. 
TABLE V. TOTAL RISK SCORES

\begin{tabular}{|c|c|c|c|c|}
\hline \multirow{2}{*}{ Enterprise } & \multicolumn{4}{|c|}{ Fire risk final scores of enterprises (\%) } \\
\cline { 2 - 5 } & $\begin{array}{c}\text { Building } \\
\text { properties }\end{array}$ & $\begin{array}{c}\text { Fire safety } \\
\text { systems }\end{array}$ & $\begin{array}{c}\text { Management } \\
\text { systems }\end{array}$ & $\begin{array}{c}\text { Total } \\
\text { score }\end{array}$ \\
\hline E17 & 42,17 & 47.62 & 10.21 & 100 \\
\hline E41 & 42.17 & 47.62 & 10.21 & 100 \\
\hline E5 & 42.17 & 47.62 & 10.21 & 100 \\
\hline E19 & 42.17 & 47.62 & 7.5 & 97.29 \\
\hline E39 & 42.17 & 47.16 & 7.5 & 96.83 \\
\hline E23 & 42.17 & 45.94 & 7.5 & 95.61 \\
\hline E18 & 42.17 & 45.28 & 7.5 & 94.95 \\
\hline$\ldots$ & $\ldots$ & 47.62 & 3.7 & 93.49 \\
\hline$\ldots$ & $\ldots$ & $\ldots$ & $\ldots$ & $\ldots$ \\
\hline E21 & 9.42 & 31.8 & $\ldots$ & $\ldots$ \\
\hline E1 & 21.88 & 31.65 & 7.5 & 61.18 \\
\hline E45 & 21.88 & 30.2 & 7.5 & 61.03 \\
\hline E22 & 21.88 & 29.58 & 7.5 & 59.58 \\
\hline E33 & 21.88 & 25.99 & 7.5 & 59.06 \\
\hline E43 & 21.88 & 31.51 & 0 & 53.39 \\
\hline E24 & 21.88 & 23.95 & 7.5 & 53.33 \\
\hline E4 & 21.88 & 22.34 & 2.39 & 47.61 \\
\hline Average & 27.87 & 39.55 & 6.96 & 74.68 \\
\hline
\end{tabular}

TABLE VI. FIRE SAFETY RISK FACTORS

\begin{tabular}{|c|c|c|c|}
\hline & Mean & Weighted & $\begin{array}{c}\text { Normalized } \\
\text { weighted mean }\end{array}$ \\
\hline Building properties & 27.8651 & 42.17 & 37.5243 \\
\hline Fire safety systems & 39.5493 & 47.67 & 60.2049 \\
\hline Management systems & 6.9649 & 10.21 & 2.2709 \\
\hline Total score & 74.6807 & 100.00 & 100.00 \\
\hline
\end{tabular}

Descriptive statistics of the study according to the sectors in which the enterprises operate are given in Table VII. Although the frequencies are very different, this Table can give overview information.

TABLE VII. DESCRIPTIVE SECTOR STATISTICS

\begin{tabular}{|c|c|c|c|c|c|}
\hline & N & Mean & Minimum & Maximum & Std. Dev. \\
\hline $\begin{array}{c}\text { Machine } \\
\text { Production }\end{array}$ & 25 & 77.4104 & 53.33 & 100.00 & 14.40924 \\
\hline Textile & 5 & 64.7620 & 47.61 & 72.07 & 10.44201 \\
\hline Hospital & 5 & 70.7600 & 55.37 & 90.48 & 13.50202 \\
\hline Warehouse & 5 & 76.0620 & 63.10 & 95.61 & 13.22125 \\
\hline Accommodation & 3 & 75.9533 & 53.39 & 100.00 & 23.34038 \\
\hline $\begin{array}{c}\text { Administrative } \\
\text { building }\end{array}$ & 2 & 69.7950 & 59.58 & 80.01 & 14.44619 \\
\hline Total & $\mathbf{4 5}$ & $\mathbf{7 4 . 6 8 0 7}$ & $\mathbf{4 7 . 6 1}$ & $\mathbf{1 0 0 . 0 0}$ & $\mathbf{1 4 . 2 7 2 5 2}$ \\
\hline
\end{tabular}

Among the 45 studied enterprises, only 3 scored 100 full points according to the fire risk ranking method, whereas 30 with a score below 80 were found. Of these, 6 had a very low score, below 60 points. According to the results, only $6.6 \%$ of the enterprises are in compliance with legislations and standards, about $67 \%$ are inadequate in terms of fire safety, partly or mostly, and continue to operate under a serious fire risk. Some of the facilities had structural alterations to buildings added after inspections. There are cases of inadequate training of firefighting squads and delays and lack of discipline while performing fire drills. It has been observed that emergency action plans are outdated in some enterprises. Fire escape routes are not clear from obstacles and are often used as temporary storage areas.

\section{CONCLUSIONS}

The fire safety level of many industrial buildings is not in line with current legislations and standards. Insufficient care and control comes at the forefront of this situation. Many workplaces do not have daily, weekly, monthly, and yearly maintenance and inspection, are non-functioning or have defective or disabled installations. Enterprises operating under these conditions are at serious fire risk. In addition, it is costly and takes a long time to make the majority of old buildings compliant with legislation and standards. As the enterprises avoid this cost and time loss, the installations are not secured. There are dangerous production processes in manufacturing enterprises that increase the fire risk compared to other businesses. Fire risks in these enterprises may arise from building designs, raw materials and equipment used, and from flawed or uncontrolled fire installations. During the periodic inspections of the fire systems, the risk analysis made in the form of a checklist is insufficient because it does not contain quantitative data. Existing conventional standards and methods cause limited and inadequate assessments of fire safety performance of the enterprises, often consisting of old buildings with poor infrastructure. For this reason, a holistic approach that allows quantitative assessments such as ranking systems can be preferred in fire risk analysis. Another advantage of the ranking systems is their cost effectiveness and ease of use.

The ranking method has been proposed and applied in structures such as high-rise office buildings and student dormitories. However, it is also suggested that the fire safety levels of different building types should be examined in more detail and be supported by different methods. The importance of fire risk assessment and inspection of fire safety systems has been increased with the developing technology and legal obligations. In order to create a safer working environment for the employees and the people living in the immediate vicinity of the factory, the risk of fire must be determined realistically and appropriate methods should be developed. In this paper, a case study has been done on this subject. In this study, FAHP and ranking methods were utilized. There are only a few similar studies on occupational health in the literature.

\section{REFERENCES}

[1] M. D. A. | www.mavigen.com, "Istanbul Fire Department," Istanbul Fire Department. http://itfaiye.ibb.gov.tr/en/ (accessed Jun. 18, 2020).

[2] M. Oturakci and C. Dagsuyu, "Fuzzy Fine - Kinney Approach in Risk Assessment and an Application," (in Turkish), Karaelmas Journal of Occupational Health and Safety, vol. 1, no. 1, pp. 17-25, 2017.

[3] "galatasaray_universitesi_yangini.pdf," (in Turkish), Accessed: Jun. 18, 2020. [Online]. Available: http://www.yangin.org/dosyalar/galatasaray _universitesi_yangini.pdf.

[4] S. Manchester and P. Bardos, "Fire Hazards from self-heating at Composting and Waste Processing Sites," Environmental Technology Limited, vol. 1, no. 1, pp. 1-9, Jan. 2004.

[5] I. D. Prete, G. Cefarelli, and E. Nigro, "Calibration of a simplified method for fire resistance assessment of partially encased composite beams," Journal of Structural Fire Engineering, vol. 7, no. 3, pp. 262282, Jan. 2016, doi: 10.1108/JSFE-09-2016-019. 
[6] F. Demirel and E. Ozkan, "Fire safety measures for structural steel components," Journal of the Faculty of Engineering and Architecture of Gazi University, vol. 18, no. 1, pp. 89-107, Dec. 2003.

[7] Q. Wang, H. Wang, and Z. Qi, "An application of nonlinear fuzzy analytic hierarchy process in safety evaluation of coal mine," Safety Science, vol. 86, pp. 78-87, Jul. 2016, doi: 10.1016/j.ssci.2016.02.012.

[8] B. Jiangdong, Z. Jingdong, L. Fei, L. Chaoyang, and S. Shuiping, "Social benefits of the mine occupational health and safety management systems of mines in China and Sweden based on a fuzzy analytic hierarchy process: A comparative study," vol. 31, no. 6, pp. 3113-3120, Dec. 2016.

[9] H. X. Li, M. Al-Hussein, Z. Lei, and Z. Ajweh, "Risk identification and assessment of modular construction utilizing fuzzy analytic hierarchy process (AHP) and simulation," Canadian Journal of Civil Engineering, vol. 40, no. 12, pp. 1184-1195, Dec. 2013, doi: 10.1139/cjce-2013-0013.

[10] M. Dagdeviren and I. Yuksel, "Developing a fuzzy analytic hierarchy process (AHP) model for behavior-based safety management," Information Sciences, vol. 178, no. 6, pp. 1717-1733, Mar. 2008, doi: 10.1016/j.ins.2007.10.016.

[11] P. Jiang, H. Yang, B. Peng, and M. Yu, "Fuzzy Analytic Hierarchy Process Assessment Model for Gas Station Safety Status and Its Application," Industrial Safety and Environmental Protection, Accessed: Jun. 18, 2020. [Online]. Available: http://en.cnki.com.cn/Article en/ CJFDTotal-GYAF200802023.htm.

[12] M. An, S. Huang, and C. Baker, "Railway risk assessment - The fuzzy reasoning approach and fuzzy analytic hierarchy process approaches: A case study of shunting at Waterloo depot," Proceedings of the Institution of Mechanical Engineers, Part F: Journal of Rail and Rapid Transit, vol. 221, no. 3, pp. 365-383, May 2007, doi: 10.1243/09544097JRRT106.

[13] K. Webster, C. Jardine, S. Cash, and L. Mcmullen, "Risk Ranking: Investigating Expert and Public Differences in Evaluating Food Safety Hazards," Journal of food protection, vol. 73, no. 10, pp. 1875-1885, Oct. 2010, doi: 10.4315/0362-028X-73.10.1875.

[14] Y. Duo, Z. Wu, L. Wei, R. Kang, and A. Lou, "Studies for the accidental risk ranking of major hazard installations," Journal of Safety Science and Technology, no. 6, pp. 19-23, 2006.

[15] S. M. Lo, B. Q. Hu, M. Liu, and K. K. Yuen, "On the use of reliability interval method and grey relational model for fire safety ranking of existing buildings," Fire Technology, vol. 41, no. 4, pp. 255-270, Oct. 2005, doi: 10.1007/s10694-005-3732-9.

[16] W. K. Chow and G. C. H. Lui, “A proposed fire safety ranking system for karaoke establishments and its comparison with the NFPA-fire safety evaluation system," Building and Environment, vol. 37, no. 6, pp. 647656, Jun. 2002, doi: 10.1016/S0360-1323(01)00073-7.

[17] L. Shi, R. Zhang, Q. Xie, and L. Fu, "Improving analytic hierarchy process applied to fire risk analysis of public building," Chinese Science Bulletin, vol. 54, no. 8, pp. 1442-1450, Apr. 2009, doi: 10.1007/s11434009-0056-z.

[18] S. W. Kim, A. Wall, J. Wang, and Y. S. Kwon, "Application of AHP to fire safety based decision making of a passenger ship," OPSEARCH, vol. 45, no. 3, pp. 249-262, Sep. 2008, doi: 10.1007/BF03398817.

[19] A. Paralikas and A. Lygeros, "A Multi-Criteria and Fuzzy Logic Based Methodology for the Relative Ranking of the Fire Hazard of Chemical Substances and Installations," Process Safety and Environmental Protection - PROCESS SAF ENVIRON PROT, vol. 83, no. 2, pp. 122134, Mar. 2005, doi: 10.1205/psep.04236.

[20] O. Tezcan, "Analytic Hierarchy Process Method and Application in Area Selection of Ready Mixed Concrete Plant", (in Turkish), Turkiye Hazır Beton Birligi Dergisi, vol. 86, no. 1, pp. 58-62, 2007

[21] A. Goksu, "Fuzzy Analytic Hierarchy Process and Its Application of University Preference Ranking," The Journal of Faculty of Economics and Administrative Sciences, vol. 13, no. 3, pp. 1-26, 2008.

[22] E. Ozgormus, O. Mutlu, and H. Guner, "Bulanik AHP ile Personel Secimi," (in Turkish), presented at the Istanbul Ticaret Universitesi V. Ulusal Uretim Arastirmaları Sempozyumu, Istanbul,Turkey, Nov. 2005.
[23] N. Erginel, "Tasarım hata turu ve etkileri analizinin etkinligi icin bir model ve uygulaması," Endustri Muhendisligi, vol. 15, no. 3, pp. 17-26, 2004.

[24] S. Alp and C. E. Gundogdu, "Kurulus yeri seciminde analitik hiyerarsi prosesi ve bulanık analitik hiyerarsi prosesi uygulaması," (in Turkish), Dokuz Eylul Universitesi Sosyal Bilimler Enstitusu Dergisi, vol. 14, no. 1, pp. 7-25, 2012.

[25] C.-H. Cheng, "Evaluating naval tactical missile systems by fuzzy AHP based on the grade value of membership function," European Journal of Operational Research, vol. 96, no. 2, pp. 343-350, Jan. 1997, doi: 10.1016/S0377-2217(96)00026-4.

[26] L. C. Leung and D. Cao, "On consistency and ranking of alternatives in fuzzy AHP," European Journal of Operational Research, vol. 124, no. 1, pp. 102-113, Jul. 2000, doi: 10.1016/S0377-2217(99)00118-6.

[27] A. Ozdagoglu, "Bulanık AHP yaklaşımında duyarlılık analizleri : yeni bir hammadde tedarikcisinin cozume eklenmesi," (in Turkish), Istanbul Ticaret Universitesi Fen Bilimleri Dergisi, vol. 7, no. 13, pp. 51-72, 2008.

[28] H. Canli and A. Kandakoglu, "A fuzzy AHP model for air force comparison," Journal Of Aeronautics And Space Technologies, vol. 3, no. 1, pp. 71-82, Jan. 2007.

[29] C. Da-Yong, "Applications of the extent analysis method on fuzzy AHP," European Journal of Operational Research, vol. 3, no. 95, pp. 649-655, 1996.

[30] M. A. Hassanain, M. A. Hafeez, and M. O. Sanni-Anibire, "A ranking system for fire safety performance of student housing facilities," Safety Science, vol. 92, pp. 116-127, Feb. 2017, doi: 10.1016/j.ssci.2016.10.002.

[31] L. Wong and S. Lau, "A Fire Safety Evaluation System for Prioritizing Fire Improvements in Old High-rise Buildings in Hong Kong," Fire Technology, vol. 43, pp. 233-249, Jan. 2007, doi: 10.1007/s10694-0070014-8.

[32] M. J. Hurley et al., Eds., SFPE Handbook of Fire Protection Engineering, 5th ed. New York, NY, USA: Springer-Verlag, 2016.

[33] S. M. Lo, "A Fire Safety Assessment System for Existing Buildings," Fire Technology, vol. 35, no. 2, pp. 131-152, May 1999, doi: 10.1023/A: 1015463821818.

[34] D. F. Li, J. X. Nan, and M. J. Zhang, "A Ranking Method of Triangular Intuitionistic Fuzzy Numbers and Application to Decision Making," International Journal of Computational Intelligence Systems, vol. 3, no. 5, pp. 522-530, Oct. 2010, doi: 10.1080/18756891.2010.9727719.

[35] W. K. Chow, "Proposed fire safety ranking system EB-FSRS for existing high-rise nonresidential buildings in Hong Kong," Journal of Architectural Engineering, vol. 8, no. 4, pp. 116-124, 2002.

[36] J. M. Watts, "Fire Risk Assessment Using Multiattribute Evaluation," Fire Safety Science, vol. 5, pp. 679-690, 1997, doi: 10.3801/IAFSS.FSS.5-679.

[37] NFPA 101A: Guide on Alternative Approaches to Life Safety. Quincy, MA, USA: National Fire Protection Association, 1995.

[38] J. M. Watts, "Analysis of the NFPA Fire Safety Evaluation System for Business Occupancies," Fire Technology, vol. 33, no. 3, pp. 276-282, Sep. 1997, doi: 10.1023/A:1015323923693.

[39] W. K. Chow and G. C. H. Lui, "Fire safety facilities assessment for karaokes," Facilities, vol. 20, no. 13/14, pp. 441-449, Jan. 2002, doi: 10.1108/02637702010454395.

[40] J. M. Watts and M. E. Kaplan, "Fire Risk Index for Historic Buildings," Fire Technology, vol. 37, no. 2, pp. 167-180, Apr. 2001, doi: 10.1023/A: 1011649802894.

[41] A. G. Copping, "Application of a Systematic Fire Safety Evaluation Procedure in the Protection of Historic Property," Fire Protection Engineering, vol. 14, pp. 12-17, 2002. 